\title{
Large-scale tropical movements and diving behavior of white sharks Carcharodon carcharias tagged off New Zealand
}

\author{
R. Bonfil ${ }^{1, *}$, M. P. Francis ${ }^{2}$, C. Duffy ${ }^{3}$, M. J. Manning ${ }^{2, \mp}$, S. O'Brien ${ }^{4}$ \\ ${ }^{1} 2233$ Caton Ave. 5C, Brooklyn, New York 11226, USA \\ ${ }^{2}$ National Institute of Water and Atmospheric Research, 301 Evans Bay Parade, Greta Point, Wellington 6021, New Zealand \\ ${ }^{3}$ Department of Conservation, Private Bag 68908, Newton, Auckland 1145, New Zealand \\ ${ }^{4}$ School of Aquatic \& Fishery Sciences, University of Washington, 1122 NE Boat St., Seattle, Washington 98105, USA
}

\begin{abstract}
Recent advances in our understanding of the spatial behavior of white sharks have been based on only 3 geographical areas: the waters off Australia, southern Africa, and the northeast Pacific Ocean. Here we report results from the first study in New Zealand waters using satellite tags to study sharks. We attached pop-up archival tags to 4 white sharks Carcharodon carcharias at the Chatham Islands, New Zealand, during April 2005. One tag released prematurely, but 3 others showed long-distance northward movements of 1000 to $3000 \mathrm{~km}$ across the open ocean, with 2 sharks moving to the tropical islands of New Caledonia and Vanuatu. Our results are similar to recent findings elsewhere of fast oceanic travel and well oriented navigation. Circumstantial information suggests that some of these movements could be part of a regular foraging migration where white sharks visit humpback whale wintering grounds to feed on carcasses and prey on newborn calves. Before embarking on large-scale movements, all sharks remained over the continental shelf near the Chatham Islands for 2.6 to $5.0 \mathrm{mo}$, rarely swimming deeper than $100 \mathrm{~m}$. In contrast, during oceanic large-scale movements, they spent most of their time in the top $1 \mathrm{~m}$ of water, showing periodic dives to depths over $900 \mathrm{~m}$. The diving behavior in combination with the large-scale movements from temperate to tropical waters results in the sharks experiencing a very wide range of water temperatures.
\end{abstract}

KEY WORDS: Great white shark $\cdot$ Archival satellite tags $\cdot$ Southwest Pacific Ocean

\section{INTRODUCTION}

The white shark Carcharodon carcharias (also known as the great white shark) is a globally distributed apex predator, with reported centers of abundance in temperate and sub-tropical waters (Compagno 2001). Negative abundance trends and rapid population declines reported in several range states have highlighted the need for improved knowledge of this species (Malcolm et al. 2001, Soldo \& Jardas 2002, Anonymous 2004), and have led to its protection in a number of countries as well as its inclusion on Appendix II of the Convention for International Trade in Endangered Species of Animals and Plants (CITES) and Appendices I and II of the Convention on the Conservation of Migratory Species of Wild Animals (CMS).

As recently as 2001, the white shark was considered to be chiefly an inhabitant of continental and insular shelves, and its migratory habits were virtually unknown (Compagno 2001). However, recent research through satellite-linked tags has demonstrated that besides spending extended periods of time in preferred coastal areas, white sharks commonly venture thousands of kilometers into the open ocean (Boustany et al. 2002) and undertake regular long-distance coastal migrations, often returning to sites to which they show a high degree of fidelity (Bonfil et al. 2005, Bruce et al. 2006, Weng et al. 2007a,b). One white 
shark made an impressive and fast transoceanic return migration, covering more than $22000 \mathrm{~km}$ in less than 9 mo (Bonfil et al. 2005). White sharks also display different diving behaviors during oceanic versus shelf residence, and Bonfil et al. (2005) and Weng et al. (2007a) speculated that celestial clues are used during oceanic navigation.

White sharks are common in New Zealand waters and were recently protected within its Territorial Sea and Exclusive Economic Zone, but in this part of their range, there has been little research on their biology, including movements. Here we present data on the meso- and macro-scale movements and diving behavior of 3 white sharks tagged with archival satellite tags at the Chatham Islands, New Zealand.

\section{MATERIALS AND METHODS}

Satellite tagging. Four white sharks (3 females, 1 male) were tagged with pop-up archival transmitting tags (PAT4 tags; Wildlife Computers) during April 2005 at Star Keys, Chatham Islands, New Zealand $\left(175^{\circ}\right.$ $59.16^{\prime} \mathrm{W}, 44^{\circ} 13.40^{\prime} \mathrm{S}$; Table 1). All sharks were tagged free-swimming, following the procedure described in Bonfil et al. (2005). Tagged sharks were sexed visually from diving cages or from the surface as they passed close to the boat. Shark size was estimated visually by at least 2 experienced observers and ranged between ca. 350 and $450 \mathrm{~cm}$ in total length (TL; Table 1). Tags were deployed for 3 to 6 mo (Table 1) and programmed to record depth, temperature, and light measurements at $60 \mathrm{~s}$ intervals. Limits for depth bins are shown in Fig. 4; upper limits for temperature bins were $4,6,8$, $10,12,14,16,18,20,23,26$, and $60^{\circ} \mathrm{C}$. Archival data were transmitted to Argos satellites in $6 \mathrm{~h}$ bins (starting at 00:00, 06:00, 12:00, and 18:00 h local time).

Data analysis. Daily shark positions were estimated from ambient light-level data collected by PAT4 tags using the geolocation algorithms implemented in software available from www.wildlifecomputers.com (WC-AMP 1.01.009, WC-GPE 1.01.0005). To reduce the inherent uncertainty of these estimates (Musyl et al. 2001, Itoh et al. 2003, Wilson et al. 2007), revised 'most-probable' daily positions were estimated by Kalman filter analysis. The model assumed was the Nielsen et al. (2006) extension of the model of Sibert et al. (2003) incorporating sea-surface temperature (SST); the 'solstice' error model was assumed in all fits.

The number of data points fitted to each track is listed in Table 2. Days for which PAT-measured SST data were implausible (observed SST above $35^{\circ} \mathrm{C}$ ) were omitted from the analysis. The deployment and pop-up positions (Table 1) were assumed by the Kalman filter fitting routine to be known without error. Longitude and SST bias were not estimated, and latitude bias was estimated in all fits. Composite SST field data on a $1^{\circ}$ longitude $\times 1^{\circ}$ latitude grid for the dates and area of interest and averaged over consecutive $8 \mathrm{~d}$ periods were downloaded from the online NMFS atlas deposited at the University of Hawaii and used in the model fits as described by Nielsen et al. (2006). Most-probable position estimates and surrounding confidence regions (within $2 \mathrm{SE}$ ) were extracted from the fitted model object for each track.

Approximate departure dates from the Chatham Islands were estimated by simultaneous examination of temporal changes in longitude, depth, and temperature. Missing data prevented exact determination of the departure dates, but errors were probably minimal $(\sim \pm 2$ d). Oceanic travel swimming speeds were estimated based on great circle distances traveled from the Chatham Islands to the pop-up points and time spent traveling.

For days with no PAT4 depth-temperature (PDT) profile data in the transmitted data summaries, we conservatively estimated these values from the $6 \mathrm{~h}$ bin data where they existed: minimum depths and temper-

Table 1. Carcharodon carcharias. Details of tag deployments on white sharks at the Star Keys, Chatham Islands, New Zealand. Speed estimates are for oceanic traveling, and are not based on the entire deployment time period. Dates are in Universal Time. F: female; M: male; Est. TL: estimated total length; n/a: not available

\begin{tabular}{|c|c|c|c|c|c|c|c|c|c|c|}
\hline Tag no. & Sex & Est. TL (m) & $\begin{array}{c}\text { Tagging date } \\
\qquad(2005)\end{array}$ & $\begin{array}{c}\text { Pop-up date } \\
\text { (2005) }\end{array}$ & $\begin{array}{l}\text { Pop-up } \\
\text { location }\end{array}$ & $\begin{array}{l}\text { Argos pop-up } \\
\text { location class }\end{array}$ & $\begin{array}{c}\text { Distance } \\
\text { traveled }(\mathrm{km})\end{array}$ & $\begin{array}{l}\text { Deployme } \\
\text { Programmed }\end{array}$ & $\begin{array}{l}\text { nt (d) } \\
\text { Actual }\end{array}$ & $\begin{array}{c}\text { Speed } \\
\left(\mathrm{km} \mathrm{h}^{-1}\right)\end{array}$ \\
\hline 57033 & F & 4.2 to 4.5 & 7 Apr & $5 \mathrm{Jul}$ & $\begin{array}{c}172^{\circ} 02.1^{\prime} \mathrm{W} \\
35^{\circ} 25.4^{\prime} \mathrm{S}\end{array}$ & 1 & 1036 & 89 & 89 & 5.4 \\
\hline 57034 & F & 3.5 & 9 Apr & $14 \mathrm{Apr}$ & $\begin{array}{c}176^{\circ} 17.4^{\prime} \mathrm{W} \\
43^{\circ} 45.6^{\prime} \mathrm{S}\end{array}$ & $\mathrm{n} / \mathrm{a}$ & $\mathrm{n} / \mathrm{a}$ & 120 & 5 & $\mathrm{n} / \mathrm{a}$ \\
\hline 57035 & F & 4.0 & 9 Apr & $5 \mathrm{Sep}$ & $\begin{array}{c}167^{\circ} 09.3^{\prime} \mathrm{E} \\
22^{\circ} 45.3^{\prime} \mathrm{S}\end{array}$ & 1 & 2847 & 149 & 149 & 3.7 \\
\hline 57036 & M & 3.2 to 3.5 & $8 \mathrm{Apr}$ & 5 Oct & $\begin{array}{c}169^{\circ} 38.7^{\prime} \mathrm{E} \\
21^{\circ} 11.2^{\prime} \mathrm{S}\end{array}$ & 2 & 2884 & 180 & 181 & 4.3 \\
\hline
\end{tabular}


Table 2. Carcharodon carcharias. Numerical results of Kalman filter model fits. N: number of observations fitted to in each track; LL: model log-likelihood; $p$ : number of model free parameters; Est.: model parameter estimate; SD: model parameter standard deviation; $u, v$, and $D$ : movement parameters from the Kalman transition equation; $b_{\text {long, }}, b_{\text {lat, }}, b_{\mathrm{SST}}, \sigma_{\text {long, }}, \sigma_{\text {lat, }}$ and $\sigma_{\mathrm{SST}}$ : bias and SD parameters; $a_{0}$ and $b_{0}$ : solstice error model parameters from the measurement equation. See Nielsen et al. (2006) for a description of model parameters and their derivation

\begin{tabular}{|c|c|c|c|c|c|c|c|c|c|c|c|c|c|c|c|}
\hline \multirow[b]{2}{*}{ Tag } & \multirow[b]{2}{*}{$\mathrm{N}$} & \multirow[b]{2}{*}{ LL } & \multirow[b]{2}{*}{$p$} & & \multirow[b]{2}{*}{$u$} & \multirow[b]{2}{*}{ V } & \multirow[b]{2}{*}{$D$} & \multirow[b]{2}{*}{$b_{\text {long }}$} & \multicolumn{3}{|c|}{ Model parameters - } & \multirow[b]{2}{*}{$\sigma_{\text {lat }}$} & \multirow[b]{2}{*}{$\sigma_{\mathrm{SST}}$} & \multirow[b]{2}{*}{$a_{0}$} & \multirow[b]{2}{*}{$b_{0}$} \\
\hline & & & & & & & & & $b_{\text {lat }}$ & $b_{\mathrm{SST}}$ & $\sigma_{\text {long }}$ & & & & \\
\hline \multirow[t]{2}{*}{57033} & 59 & -274.998 & 9 & Est. & 3.78 & 10.40 & 429.36 & 0 & 0.18 & 0 & 0.18 & 1.70 & 0.24 & 0.03 & 25.56 \\
\hline & & & & $\mathrm{SD}$ & 0.83 & 0.97 & 82.04 & - & 0.45 & - & 0.17 & 0.30 & 0.03 & 0.02 & 5.11 \\
\hline \multirow[t]{2}{*}{57035} & 90 & -446.223 & 9 & Est. & -5.10 & 8.20 & 556.83 & 0 & 0.01 & 0 & 0.45 & 1.63 & 0.25 & 0.05 & 26.89 \\
\hline & & & & SD & 1.15 & 0.86 & 74.72 & - & 0.36 & - & 0.08 & 0.27 & 0.03 & 0.02 & 4.27 \\
\hline \multirow[t]{2}{*}{57036} & 79 & -455.196 & 9 & Est. & -4.69 & 8.37 & 764.04 & 0 & 5.82 & 0 & 0.28 & 2.81 & 0.35 & 0.01 & 9.68 \\
\hline & & & & SD & 1.08 & 1.81 & 91.34 & - & 0.52 & - & 0.07 & 0.28 & 0.02 & 0.01 & 3.03 \\
\hline
\end{tabular}

atures were estimated as the upper (deeper, warmer) bound of the lowest bin in each $24 \mathrm{~h}$ period, and maximum depths and temperatures were estimated as the lower (shallower, cooler) bound of the highest bin in each $24 \mathrm{~h}$ period. This procedure allowed approximate temporal interpolation between daily PDT estimates but at the expense of underestimating the maxima and overestimating the minima.

\section{RESULTS}

We successfully tracked 3 sharks for periods of 89 , 149, and 181 d (Table 1). Summary data transmitted for each tag via the Argos system comprised time-at-depth data, time-at-temperature data, depth-temperature profile data, and geolocation estimates of longitude and latitude based on light readings.

\section{Geographic movements}

A 3.8 to $4.0 \mathrm{~m}$ TL female white shark (Tag 57034, programmed for a 4 mo deployment) prematurely shed its tag $5 \mathrm{~d}$ after tagging. This tag reported to the Argos system from $\sim 70 \mathrm{~km}$ north of the tagging site, but the tag may have drifted from elsewhere before transmitting (it was programmed to detach and transmit after $168 \mathrm{~h}$ at a constant depth).

A second female white shark, 4.2 to $4.5 \mathrm{~m}$ TL (Tag 57033, a 3 mo deployment) traveled to the Louisville Seamount Chain, $1036 \mathrm{~km}$ northeast of the Chatham Islands (Table 1). The pop-up region has no shallow water: most of the sea floor is at depths $>4000 \mathrm{~m}$, although several seamounts within 55 to $90 \mathrm{~km}$ rise to depths of 2400 to $3700 \mathrm{~m}$. A third female white shark, ca. $4.0 \mathrm{~m}$ TL (Tag 57035, a 5 mo deployment) traveled to the southern shelf of New Caledonia, $2847 \mathrm{~km}$ northwest of the Chatham Islands. The fourth shark, a 3.2 to $3.5 \mathrm{~m}$ TL male (Tag 57036, a 6 mo deployment) moved to southern Vanuatu, having traveled $2884 \mathrm{~km}$ from the tagging site (Fig. 1).

The Kalman filter-corrected tracks suggest that the sharks traveled directionally to pop-up locations (Fig. 2). Numerical results of the Kalman model fits are provided in Table 2. Sharks 57035 and 57036 visited the northeastern coast of New Zealand before continuing on a direct route to the tropical waters of New Caledonia and Vanuatu. The estimated routes and swimming speeds suggest that these sharks did not stop in coastal waters of mainland New Zealand during their largescale movements. Estimated speeds during ocean traveling were 89 to $130 \mathrm{~km} \mathrm{~d}^{-1}$ (3.7 to $5.4 \mathrm{~km} \mathrm{~h}^{-1}$; Table 1).

The 3 white sharks we tracked remained in the vicinity of the Chatham Islands for 2.6 to 5.0 mo before embarking on oceanic large-scale movements. They left the Chatham Islands in late June (57033), early July (57035), and early September (57036; Fig. 3). Sharks 57035 and 57036 arrived in tropical waters in early August and early October, respectively.

\section{Vertical distribution}

While at the Chatham Islands, all 3 sharks remained in shallow water, rarely venturing below 75 m (Figs. 3 $\& 4$ ). Most time (mean of 3 sharks $=81.8 \%$ ) was spent between $2 \mathrm{~m}$ and $50 \mathrm{~m}$ depth. The modal depth range was slightly greater for shark 57035 (26 to $50 \mathrm{~m})$ than for the other 2 sharks (11 to $25 \mathrm{~m}$ ).

During their ocean traveling phase, the vertical distribution of the sharks changed dramatically. All 3 sharks spent most time (mean $61.6 \%$ ) at the surface ( 0 to $1 \mathrm{~m}$ depth band) but made periodic deep dives. Sharks 57033 and 57036 both dove to at least $901 \mathrm{~m}$ (maximum PDT depths for both sharks were shallower than the shallow limit of the deepest depth bin occupied), and shark 57035 dove to at least 748 m (Fig. 3). The vertical distribution pattern was bimodal, but this effect is exaggerated by the unequal depth-bin sizes. 


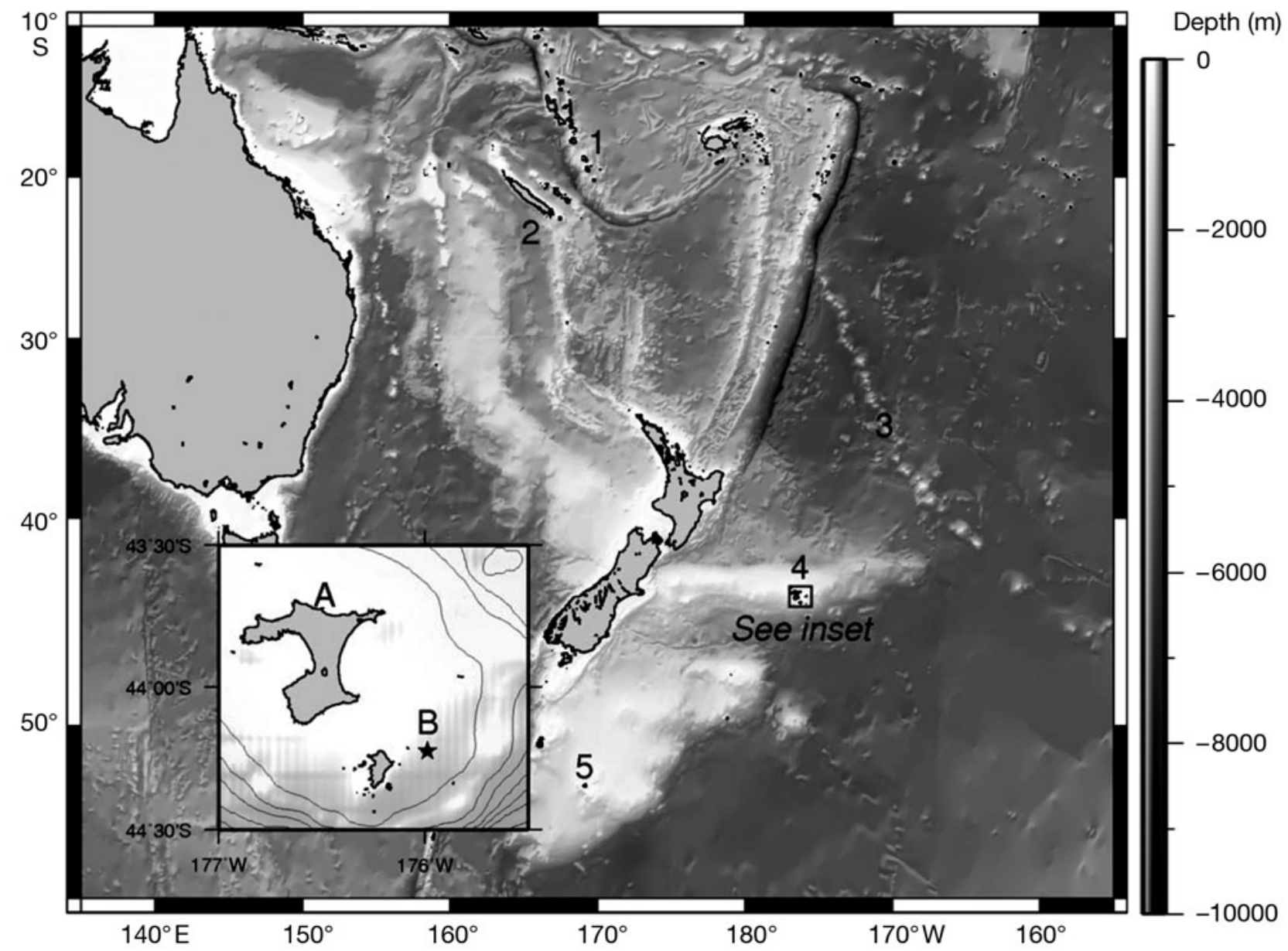

Fig. 1. Southwest Pacific Ocean showing the tagging site (star) and other locations mentioned in the text. 1: Vanuatu; 2: New Caledonia; 3: Louisville Seamount Chain; 4: Chatham Islands; 5: Campbell Island; A: Chatham Island; B: Star Keys; $100 \mathrm{~m}$ bathymetric contours are overlaid on the inset

After grouping the depth bins into equal $200 \mathrm{~m}$ intervals, the mean percentages of time spent by the 3 sharks in each depth range were $76.7 \%$ at 0 to $200 \mathrm{~m}$, $4.6 \%$ at 201 to $400 \mathrm{~m}, 8.3 \%$ at 401 to $600 \mathrm{~m}, 9.2 \%$ at 601 to $800 \mathrm{~m}$, and $1.1 \%$ at 801 to $1000 \mathrm{~m}$. The bimodal pattern persisted, and had a minimum at 201 to $400 \mathrm{~m}$, indicating that the sharks traversed these depths relatively quickly. The percentage of time spent by individual sharks deeper than $400 \mathrm{~m}$ was 11 to $30 \%$ (mean $18.7 \%$ ) and deeper than $600 \mathrm{~m}$ was 6 to $18 \%$ (mean $10.4 \%$; Fig. 4).

It was not possible to determine the frequency or duration of deep dives because of the coarse temporal resolution of the data ( $6 \mathrm{~h}$ time bins) and frequent gaps in the data series because of incomplete transmission. However, Shark 57033 made at least 2 dives deeper than $800 \mathrm{~m}$, Shark 57035 made at least 5 dives deeper than $600 \mathrm{~m}$, and Shark 57036 made at least 4 dives deeper than $600 \mathrm{~m}$ (Fig. 3). Shark 57035 displayed a third vertical distribution pattern in New Caledonian waters, intermediate between those from the Chatham
Islands and while ocean traveling (Fig. 3). She spent most of her time $(74.0 \%)$ shallower than $100 \mathrm{~m}$, but with large amounts of time between 101 and $200 \mathrm{~m}$ $(12.6 \%)$ and 201 and $400 \mathrm{~m}(12.1 \%)$. Only $1.2 \%$ of her time was spent deeper than $400 \mathrm{~m}$.

\section{Temperature ranges}

While at the Chatham Islands, all 3 sharks experienced similar, steadily declining water temperatures as winter approached (Fig. 3). Maximum and minimum temperatures differed little, consistent with the sharks inhabiting the shallow mixed layer. Water temperature was near $15^{\circ} \mathrm{C}$ when tags were deployed in April and declined to about $12^{\circ} \mathrm{C}$ in late June to early July when Sharks 57033 and 57035 departed, and about $11^{\circ} \mathrm{C}$ in early September when Shark 57036 departed.

After departure from the Chatham Islands, maximum temperatures increased rapidly as the sharks headed northwards into subtropical and tropical 


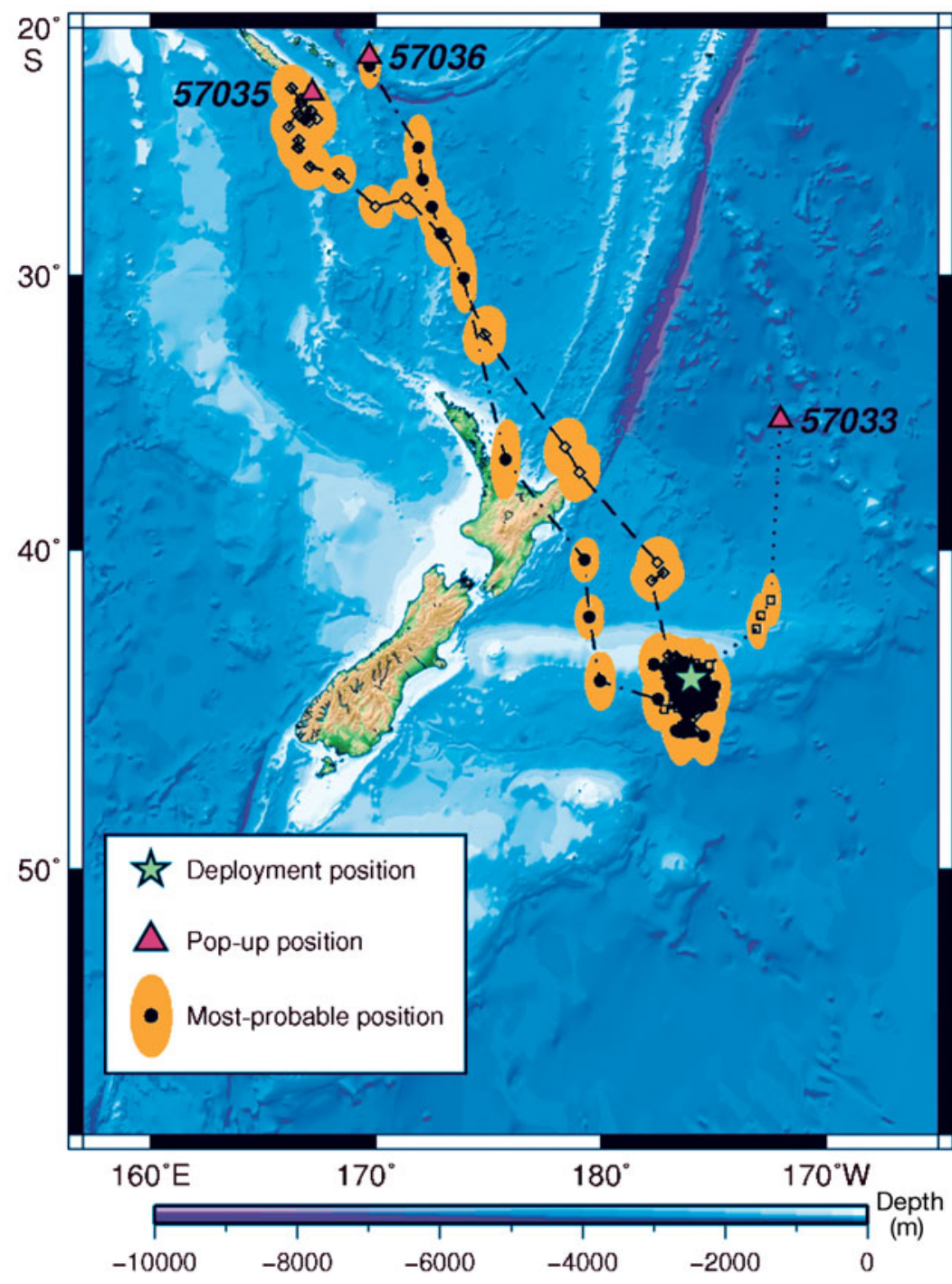

Fig. 2. Carcharodon carcharias. 'Most-probable' tracks for tagged white sharks; confidence regions ( $2 \mathrm{SE}$ ) surrounding each point are shown (orange)

\section{DISCUSSION}

\section{Geographic movements}

The 3 white sharks successfully tracked during this study appear to have remained at the Chatham Islands for several months after tagging and then made rapid, directed movements to subtropical and tropical locations. This is consistent with studies conducted elsewhere describing white shark behaviors ranging from site fidelity to trans-oceanic migrations (Strong et al. 1992, Goldman \& Anderson 1999, Boustany et al. 2002, Bonfil et al. 2005, Bruce et al. 2006, Weng et al. 2007a,b, Domeier \& Nasby-Lucas 2008). While our data do not provide unequivocal evidence for residency because light-based geolocation estimates are subject to error particularly for latitude (Musyl et al. 2001, Itoh et al. 2003), the most-probable position estimates for the 3 sharks have relatively small confidence regions and are tightly grouped around the islands (Fig. 2). Additionally, the steady decline in tag-recorded temperatures as winter approached, and the relatively shallow depths recorded during this period are also consistent with the sharks remaining in the vicinity of the Chatham Islands for 2.6 to 5.0 mo after tagging.

The Chatham Islands sharks all made extensive oceanic movements, whereas most other white sharks tagged in the Southern Hemisphere have largely remained within shelf waters when moving from temperate to lower latitudes (Bonfil et al. 2005, Bruce et al. 2006). The most notable exceptions to this are the trans-oceanic return migration of an immature female white shark between South

waters. Shark 57035 reached a plateau of about $22^{\circ} \mathrm{C}$, and a maximum of $23.8^{\circ} \mathrm{C}$ in New Caledonian waters, and Shark 57036 reached $23.4^{\circ} \mathrm{C}$ at the end of his track in southern Vanuatu. During the ocean traveling phase, minimum temperatures experienced by the sharks fluctuated markedly in concert with their diving behavior (Fig. 3). All sharks experienced temperatures less than $8^{\circ} \mathrm{C}$, with Sharks 57036 and 57033 recording the lowest values at $6.6^{\circ} \mathrm{C}$ and $6.4^{\circ} \mathrm{C}$, respectively.

As a result of their movement from temperate to tropical latitudes and deep diving behavior, our sharks experienced a wide range of temperatures $(6.4$ to $23.8^{\circ} \mathrm{C}$ ). Temperature variations of 10 to $12^{\circ} \mathrm{C}$ were often experienced in a single day by Sharks 57035 and 57036 (Fig. 3).
Africa and Western Australia (Bonfil et al. 2005) and the movement of a subadult female white shark between South Australia and the northwest coast of New Zealand (Bruce et al. 2006). The important difference between these studies and ours is that in both southern Africa and Australia, the continental shelf is continuous between tropical and temperate regions, but the Chatham Islands are in a temperate region where the continental shelf is separated from subtropical and tropical shelves by extensions of the continental slope and submarine ridges. Seasonal migration to subtropical and tropical latitudes is a common white shark behavior elsewhere (Boustany et al. 2002, Bonfil et al. 2005, Bruce et al. 2006, Weng et al. 2007a, Domeier \& Nasby-Lucas 2008), so it is not surprising that white sharks inhabiting New Zealand waters make long-distance, northward, oceanic movements. 


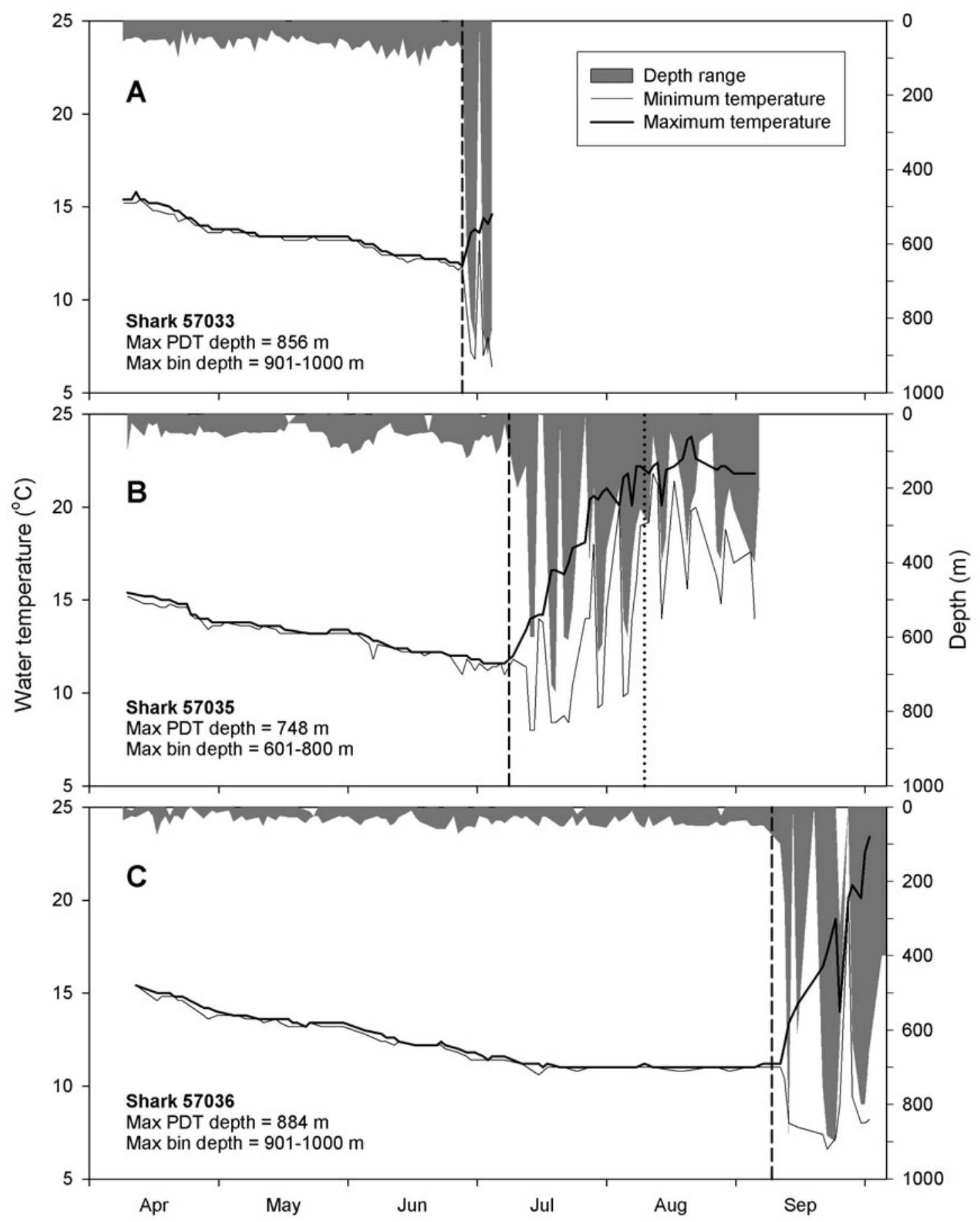

Fig. 3. Carcharodon carcharias. Depth ranges traversed by 3 tagged white sharks and ambient water temperatures recorded by the tags. Data represent minimum and maximum values recorded within a $6 \mathrm{~h}$ time interval. Vertical dashed lines indicate the approximate date of departure of each shark from the Chatham Islands. The vertical dotted line in B indicates the approximate time of arrival of shark 57035 at New Caledonia. Missing data mean that depth and temperature plots do not always correspond with each other

\section{Swimming speed}

Chatham Island white sharks maintained high swimming speeds (3.7 to $5.4 \mathrm{~km} \mathrm{~h}^{-1}$ ) during ocean crossings.
Previous estimates of white shark swimming speeds maintained for several hours or longer are mainly within the range of 2.9 to $4.5 \mathrm{~km} \mathrm{~h}^{-1}$ (Carey et al. 1982, Strong et al. 1992, Boustany et al. 2002, Klimley et al. 


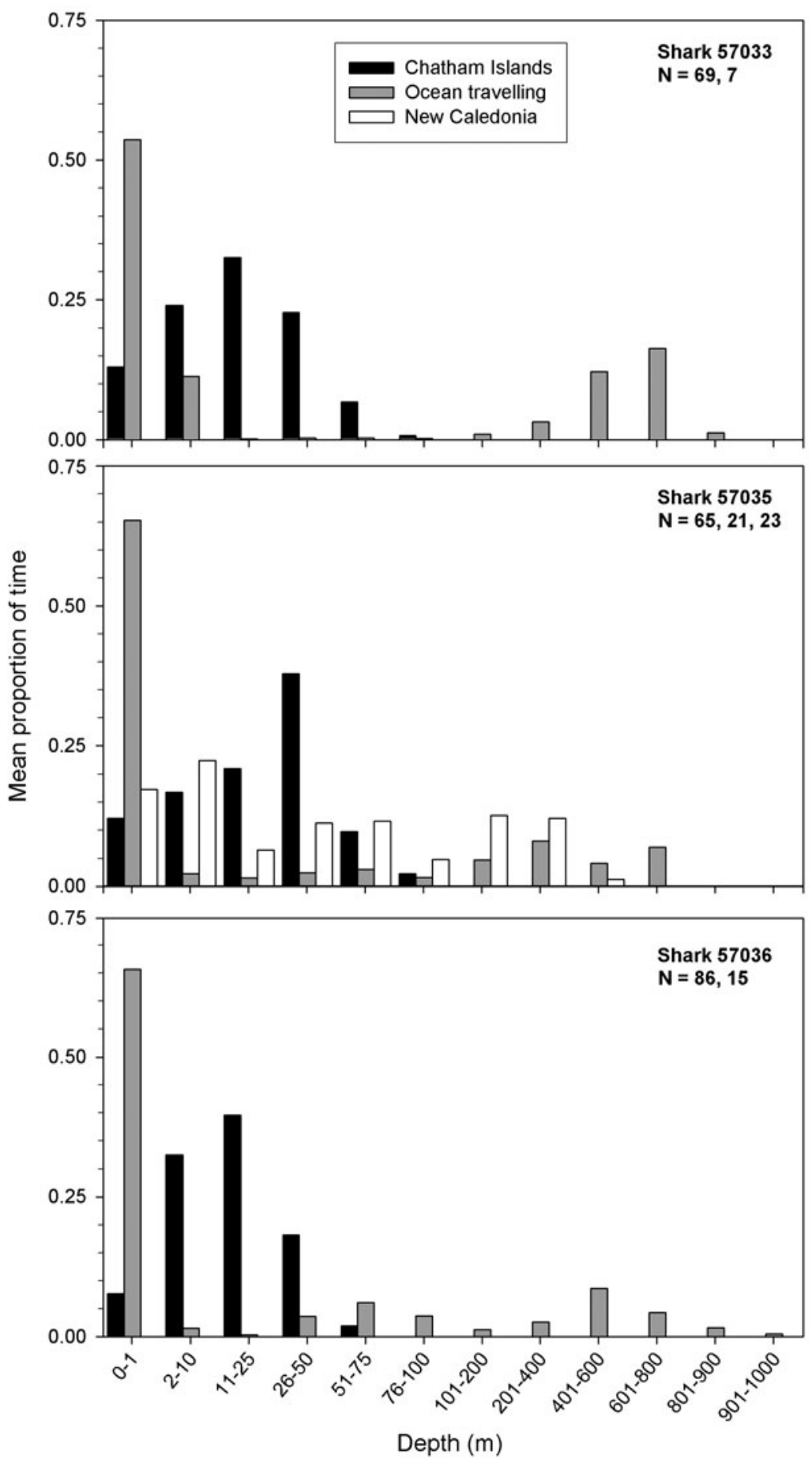

Fig. 4. Carcharodon carcharias. Time spent by 3 white sharks at different depths while at the Chatham Islands, ocean traveling, and (for Shark 57035 only) New Caledonia. N: sample sizes (number of days with data records) for Chatham Islands, ocean traveling, and New Caledonia

northeast Pacific (Weng et al. 2007b). Furthermore, Domeier \& Nasby-Lucas (2008) recorded a maximum speed of $8.0 \mathrm{~km} \mathrm{~h}^{-1}$ over a $24 \mathrm{~h}$ period for a white shark in the northeast Pacific. Thus, white sharks can make extended migrations at sustained speeds of about $5 \mathrm{~km} \mathrm{~h}^{-1}$, or $120 \mathrm{~km} \mathrm{~d}^{-1}$. In an analysis of 4 satellite-tracked Australian sharks (1.8 to $3.6 \mathrm{~m}$ TL), Bruce et al. (2006) found that swimming speed was independent of shark length. In comparison, salmon sharks Lamna ditropis also swim at relatively high speeds during oceanic travel; Weng et al. (2008) reported maximum swimming speeds of $4.29 \mathrm{~km}$ $\mathrm{h}^{-1}$ for salmon sharks in the North Pacific.

\section{Motivation for large-scale movements}

Although the motivation for white shark migrations is unknown, archival satellite tag records from the northeast Pacific suggest they may be related to foraging (Weng et al. 2007a, Domeier \& NasbyLucas 2008). However, foraging chances are likely to be higher in the areas to which our white sharks are traveling from New Zealand than in the vast oceanic region to where northeast Pacific white sharks are traveling. In our case, the tag release points and pop-up dates coincide with seasonal aggregations of large whales, particularly humpback whales Megaptera novaeangliae in tropical areas (Gaskin 1976, Garrigue \& Gill 1994, Richards 2002, Garrigue \& Russell 2004).

Data collected by Clua \& Séret (in press) indicate that white sharks occur sporadically but consistently in New Caledonian waters. They reported more than 20 occurrences in the last $30 \mathrm{yr}$.

White sharks are known to scavenge on whale carcasses (Carey et al. 1982, Long \& Jones 1996, Dudley et al. 2000) and have also been observed to attack distressed juvenile southern right whales Eubalaena australis (S. Burnell pers. comm.). Most white shark records from the Hawaiian Islands coincided with the humpback whale calving season (Novem-

2002, Bruce et al. 2006). However, a speed of $4.7 \mathrm{~km}$ $\mathrm{h}^{-1}$ was recorded during an ocean transit of ca. $11100 \mathrm{~km}$ in $99 \mathrm{~d}$ (Bonfil et al. 2005), and a maximum speed of $5.0 \mathrm{~km} \mathrm{~h}^{-1}$ was recorded for a shark tracked in the ber to May; Taylor 1985, Boustany et al. 2002, Weng et al. 2007a, Domeier \& Nasby-Lucas 2008), and similar patterns are evident in Australia (Paterson \& Paterson 1989, Bruce et al. 2006) and New Caledonia (Garrigue 
\& Gill 1994, Clua \& Séret in press). The correlation of white shark movements with those of large cetaceans in different parts of the world suggests that white sharks might travel to areas frequented by whales to exploit windfall feeding opportunities.

More research, including further satellite tagging and the development of techniques to remotely record feeding events of sharks, needs to be carried out before we can determine whether our preliminary results of white shark large-scale movements are indeed aimed at feeding on whales, whether they return to the Chatham Islands after these large-scale movements to the tropics, and whether such patterns of spatial behavior are indeed seasonal, predictable, and constitute part of a migration.

\section{Vertical behavior}

The 3 white sharks we tracked displayed a unimodal depth distribution with a preference for depths of 2 to $50 \mathrm{~m}$ while at the Chatham Islands. They rarely dove deeper than $75 \mathrm{~m}$, although depths exceeding $100 \mathrm{~m}$ exist within $9 \mathrm{~km}$ of the Star Keys tagging site. Preferences for depths shallower than $50 \mathrm{~m}$ have also been displayed by white sharks near pinniped colonies elsewhere (Strong et al. 1992, Goldman \& Anderson 1999, Boustany et al. 2002, Bruce et al. 2006, Hammerschlag et al. 2006, Weng et al. 2007b).

This behavior pattern changed abruptly after the sharks left the Chatham Islands. During ocean travelling, the Chatham Islands sharks spent most of their time at the surface (mean $62 \%$ at 0 to $1 \mathrm{~m}$ depth), punctuated by dives below $600 \mathrm{~m}$ depth. The bimodal depth distribution exhibited by the Chatham Islands sharks during oceanic travel (Fig. 4) is essentially the same as that shown by white sharks during oceanic travel in the northeast Pacific and Indian Oceans (Boustany et al. 2002, Bonfil et al. 2005, Weng et al. 2007a, Domeier \& Nasby-Lucas 2008). These results, and the regular receipt of satellite fixes from dorsal fin tags that transmit when the aerial breaks the sea surface (e.g. Bruce et al. 2006), indicate that white sharks moving in oceanic waters travel mainly at the surface. Diving to depths greater than $500 \mathrm{~m}$ is also a feature in all of these studies, suggesting that surface migration interspersed with deep diving is a routine behavioral pattern for white sharks during ocean travel. Oscillatory swimming behavior is common in large pelagic fishes, including sharks, and may serve a variety of functions in addition to foraging. These include thermoregulation (Carey \& Scharold 1990), energy conservation (Weihs 1973), and navigation using geomagnetic and/or celestial cues (Klimley et al. 2002, Bonfil et al. 2005).
Further research is required to understand the function of bimodal depth oceanic swimming behavior and the mechanisms used by white sharks to navigate during oceanic travel, and to determine whether white sharks that leave New Zealand make return large-scale movements such as those reported elsewhere (Bonfil et al. 2005, Weng et al. 2007a). Such research could also help elucidate population connectivity between the Chatham Islands, mainland New Zealand, tropical islands in the region, and Australia. The limited amount of existing information on white shark movements in this region suggests at least some movement between Australia and the main islands of New Zealand (Pardini et al. 2001, Bruce et al. 2006). Despite the sparse and infrequent records of white sharks from the tropical islands of the southwest Pacific, our data suggest that white sharks may regularly travel there from New Zealand, possibly drawn to humpback whale wintering and calving grounds.

Acknowledgements. We thank T. and S. Gregory-Hunt, G. King, and K. Scollay for their invaluable assistance in finding and tagging of sharks; and C. Garrigue (Opération Cétacés, Nouméa) for providing information on humpback whale distribution and migration around New Caledonia and the tropical South Pacific. The Wildlife Conservation Society, The Roe Foundation, the New Zealand Foundation for Research Science and Technology, and the New Zealand Department of Conservation provided financial support for this project.

\section{LITERATURE CITED}

Anonymous (2004) Inclusion of Carcharodon carcharias (white shark) on CITES Appendix II, including an annotation that states that a zero annual export quota is established for this species. Consideration of Proposals for Amendment of Appendices I and II. Convention for International Trade on Endangered Species of Flora and Fauna, 13th Conference of the Parties, Bangkok, Thailand, October 2004. Available at: www.cites.org/eng/cop/13/ raw_props.shtml

> Bonfil R, Meÿer M, Scholl MC, Johnson R and others (2005) Transoceanic migration, spatial dynamics and population linkages of white sharks. Science 310:100-103

Boustany AM, Davis SF, Pyle P, Anderson SD, Le Boeuf BJ, Block BA (2002) Expanded niche for white sharks. Nature 415:35-36

- Bruce BD, Stevens JD, Malcolm H (2006) Movements and swimming behavior of white sharks (Carcharodon carcharias) in Australian waters. Mar Biol 150:161-172

> Carey FG, Scharold JV (1990) Movements of blue sharks (Prionace glauca) in depth and course. Mar Biol 106: 329-342

Carey FG, Kanwisher JW, Brazier O, Gabrielson G, Casey JG, Pratt HL Jr (1982) Temperature and activities of a white shark, Carcharodon carcharias. Copeia 1982:254-260

Clua E, Séret B (in press) Unprovoked fatal shark attack in Lifou island (Loyalty Islands, New Caledonia, South Pacific) by a great white shark, Carcharodon carcharias. Am J Forensic Med Pathol

Compagno LJV (2001) Sharks of the world. An illustrated and 
annotated catalogue of shark species known to date. Vol. 2. Bullhead, mackerel and carpet sharks (Heterodontiformes, Lamniformes and Orectolobiformes). FAO Species Catalogue for Fishery Purposes 1. FAO, Rome

Domeier ML, Nasby-Lucas N (2008) Migration patterns of white sharks Carcharodon carcharias tagged at Guadalupe Island, Mexico, and identification of an eastern Pacific shared offshore foraging area. Mar Ecol Prog Ser 370:221-237

Dudley SFJ, Anderson-Reade MD, Thompson GS, McMullen PB (2000) Concurrent scavenging off a whale carcass by great white sharks, Carcharodon carcharias, and tiger sharks, Galeocerdo cuvier. Fish Bull 98:646-649

> Garrigue C, Gill PC (1994) Observations of humpback whales Megaptera novaeangliae in new Caledonian waters during 1991-1993. Biol Conserv 70:211-218

Garrigue C, Russell K (2004) Vanuatu. In: Rep 5th Annu Meet South Pac Whale Res Consortium, 2-6 April 2004, Byron Bay, NSW, Australia: regional updates. For consideration by The Scientific Committee of The International Whaling Commission, Sorrento. Sc/55/Sh7. Available at: www. whaleresearch.org/update_006.htm

Gaskin DE (1976) The evolution, zoogeography and ecology of Cetacea. Oceanogr Mar Biol Annu Rev 14:247-346

Goldman KJ, Anderson SD (1999) Space utilization and swimming depth of white sharks, Carcharodon carcharias, at the South Farallon Islands, central California. Environ Biol Fishes 56:351-364

Hammerschlag N, Martin RA, Fallows C (2006) Effects of environmental conditions on predator-prey interactions between white sharks (Carcharodon carcharias) and Cape fur seals (Arctocephalus pusillus pusillus) at Seal Island, South Africa. Environ Biol Fishes 76:341-350

Itoh T, Tsuji T, Nitta A (2003) Migration patterns of young Pacific bluefin tuna (Thunnus orientalis) determined with archival tags. Fish Bull 101:514-534

Klimley AP, Beavers SC, Curtis TH, Jorgensen SJ (2002) Movements and swimming behavior of three species of sharks in La Jolla Canyon, California. Environ Biol Fishes 63:117-135

Long DL, Jones RE (1996) White shark predation and scavenging on cetaceans in the eastern North Pacific Ocean. In: Klimley AP, Ainley DG (eds) Great white sharks. The biology of Carcharodon carcharias. Academic Press, San Diego, CA, p 293-307

Malcolm H, Bruce BD, Stevens JD (2001) A review of the biology and status of white sharks in Australian waters. Report to Environment Australia, Marine Species Protection Program, CSIRO Marine Research, Hobart

Musyl M, Brill RW, Curran DS, Gunn JS and others (2001) Ability of electronic archival tags to provide estimates of

Editorial responsibility: Brent Stewart,

San Diego, California, USA geographical position based on light intensity. In: Sibert JR, Nielsen JL (eds) Electronic tagging and tracking in marine fisheries. Kluwer Academic Publishers, Dordrecht, p 343-368

Nielsen A, Bigelow KA, Musyl MK, Sibert JR (2006) Improving light-based geolocation by including sea surface temperature. Fish Oceanogr 15:314-325

Pardini AT, Jones CS, Noble LR, Krieser B and others (2001) Sex-biased dispersal of great white sharks. Nature 412: 139-140

Paterson R, Paterson P (1989) The status of the recovering stock of humpback whales Megaptera novaeangliae in east Australian waters. Biol Conserv 47:33-48

Richards R (2002) Southern right whales: a reassessment of their former distribution and migration routes in New Zealand waters, including on the Kermadec Grounds. J R Soc N Z 32:355-377

Sibert JR, Muysl MK, Brill RW (2003) Horizontal movements of bigeye tuna (Thunnus obesus) near Hawaii determined by Kalman filter analysis of archival tagging data. Fish Oceanogr 12:141-151

Soldo A, Jardas I (2002) Occurrence of great white shark, Carcharodon carcharias (Linnaeus, 1758) and basking shark, Cetorhinus maximus (Gunnerus 1765) in the Eastern Adriatic and their protection. Period Biol 104:195-201

Strong WR, Murphy RC, Bruce BD, Nelson DR (1992) Movements and associated observations of bait-attracted white sharks, Carcharodon carcharias: a preliminary report. Aust J Mar Freshw Res 43:13-20

Taylor L (1985) White sharks in Hawaii: historical and contemporary records. Mem South Calif Acad Sci 9:41-48

Weihs D (1973) Mechanically efficient swimming techniques for fish with negative buoyancy. J Mar Res 31:194-209

Weng KC, Boustany AM, Pyle P, Anderson SD, Brown A, Block BA (2007a) Migration and habitat of white sharks (Carcharodon carcharias) in the eastern Pacific Ocean. Mar Biol 152:877-894

Weng KC, O'Sullivan JB, Lowe CG, Winkler CE, Dewar H, Block BA (2007b) Movements, behavior and habitat preferences of juvenile white sharks in the eastern Pacific as revealed by electronic tags. Mar Ecol Prog Ser 338: 211-224

> Weng KC, Foley DG, Ganong JE, Perle C, Shillinger GL, Block B (2008) Migration of an upper trophic level predator, the salmon shark Lamna ditropis, between distant ecoregions. Mar Ecol Prog Ser 372:253-264

Wilson SG, Stewart BS, Polovina JJ, Meekan MG, Stevens JD, Galuardi B (2007) Accuracy and precision of archival tag data: a multiple-tagging study conducted on a whale shark (Rhincodon typus) in the Indian Ocean. Fish Oceanogr 16:547-554

Submitted: September 8, 2007; Accepted: December 4, 2009 Proofs received from author(s): January 1, 2010 